\title{
PENGARUH PRODUK DAN PROMOSI TERHADAP KEPUTUSAN MENJADI NASABAH TABUNGAN MARHAMAH PADA PT. BANK SUMUT CABANG SYARIAH PADANGSIDIMPUAN
}

\author{
Budi Gautama Siregar \\ IAIN Padangsidimpuan \\ Budigautamasrg20@gmail.com
}

\begin{abstract}
The problem of this research is the number of banking institutions that operate in sharia, creating competition among banking institutions in collecting funds from the community. Evidently, the decision to become a customer of Savings Marhamah at PT. Bank SUMUT of the Sharia Branch of Padangsdimpuan which declines in 2016. Therefore, the bank can offer its products with a better strategy and expand the range and the promotional media. This type of research is descriptive quantitative research. With data source that is primary data. With a population of 8119 customers, with sampling technique using random sampling technique as much as 99 customers. Data collection techniques used are questionnaires and documentation. And tested the validity and reliability. Descriptive test and linearity test. Prerequisite test includes normality test, heteroscedasticity test and multicollinearity test. And multiple linear regression analysis techniques. The results of this study show partially ( $t$ test) states that, Product has tcount $>$ ttabel $(1.667>1.660)$ and significance level $<\alpha(0.099<0.1)$ means Product significantly influence to Customer's Decision. Promotion has t count $>$ ttable $(2.100>1.660)$ and significance level $<\alpha(0,038<0,1)$ means that Promotion has significant effect to Customer's Decision. The result of simultaneous research (F test) states that Product and Promotion have Fcount> Ftable $(5.371>2.36)$ and significance level obtained $(0.006<0,1)$ means Product and Promotion simultaneously have a significant effect to Customer's Decision. While $\mathrm{R}$ Square equal to 0.216, it means Customer Decision influenced by Product and Promotion equal to $21.6 \%$, while the other $78.4 \%$ is explained by other variable not included in this research.
\end{abstract}

Keywords: Product, Promotion, Customer Decision and Savings Marhamah

Abstrak

Masalah penelitian ini adalah banyaknya lembaga perbankan yang beroperasi secara syariah, membuat persaingan antar lembaga perbankan dalam menghimpun dana dari masyarakat. Terbukti, keputusan menjadi nasabah Tabungan Marhamah pada PT. Bank SUMUT Cabang Syariah Padangsdimpuan yang menurun pada tahun 2016. Oleh karena itu, bank dapat menawarkan produknya dengan strategi yang lebih baik dan memperluas jangkauan dan media promosi yang dilakukan. Jenis penelitian ini adalah penelitian kuantitatif deskriptif. Dengan sumber data yaitu data primer. Dengan populasi 8119 nasabah, dengan teknik pengambilan sampel menggunakan teknik random sampling sebanyak 99 nasabah. Teknik pengumpulan data yang digunakan adalah angket dan dokumentasi. Dan diuji validitas serta reliabilitasnya. Uji deskriptif dan uji linieritas. Uji prasyarat meliputi uji normalitas, uji heteroskedastisitas dan uji 
2 | TAZKIR: Jurnal Penelitian Ilmu-ilmu Sosial dan Keislaman

Vol. 04 No. 1 Juni 2018

multikolinearitas. Dan teknik analisis regresi linear berganda. Hasil penelitian ini menunjukkan secara parsial (uji t) menyatakan bahwa, Produk memiliki thitung $>$ tabel $(1,667>1,660)$ dan tingkat signifikansi $<\alpha \quad(0,099<0,1)$ artinya Produk berpengaruh signifikan terhadap Keputusan Menjadi Nasabah. Promosi memiliki thitung $>$ tabel $(2,100>1,660)$ dan tingkat signifikansi $<\alpha$ $(0,038<0,1)$ artinya Promosi berpengaruh signifikan terhadap Keputusan Menjadi Nasabah. Hasil penelitian secara simultan (uji F) menyatakan bahwa Produk dan Promosi memiliki Fhitung $>$ Ftabel $(5,371>2,36)$ dan tingkat signifikansi yang diperoleh $(0,006<0,1)$ artinya Produk dan Promosi secara simultan berpengaruh signifikan terhadap Keputusan Menjadi Nasabah. Sedangkan R Square sebesar 0,216, artinya Keputusan Nasabah dipengaruhi oleh Produk dan Promosi sebesar 21,6\%, sedangkan 78,4\% sisanya dijelaskan oleh variabel lain yang tidak dimasukkan dalam penelitian ini.

Kata Kunci : Produk, Promosi, Keputusan Menjadi Nasabah dan Tabungan Marhamah

\section{PENDAHULUAN}

Seiring dengan perkembangan dunia perbankan dari zaman ke zaman, bank bagi masyarakat yang hidup di negara-negara maju, seperti negara-negara Eropa, Amerika, dan Jepang, sudah merupakan suatu kebutuhan dasar yang harus dipenuhi. Bank merupakan mitra dalam rangka memenuhi semua kebutuhan keuangan mereka sehari-hari. Bank dijadikan sebagai tempat untuk melakukan berbagai transaksi yang berhubungan dengan keuangan seperti tempat mengamankan uang, melakukan investasi, pengiriman uang, melakukan pembayaran, atau melakukan penagihan.

Setelah perbankan konvensional berhasil membantu kebutuhan suatu negara akan lembaga keuangan. Berbagai ide untuk mengembangkan suatu lembaga keuangan dengan menggunakan sistem bagi hasil pun muncul sejak lama di negara-negara dengan penduduk mayoritas Muslim. Beberapa pemikir Muslim telah menyampaikan ide tentang perlunya suatu bank Islam, akan tetapi para pemikir Muslim pada saat itu belum memberikan uraian yang lebih rinci mengenai konsep perbankan Islam. ${ }^{1}$ pada tahun 1940-an, upaya untuk mewujudkan suatu lembaga keuangan Islam dengan basis bagi hasil mulai menampakkan bentuknya secara nyata, terutama dengan berdirinya suatu lembaga keuangan yang mengelola dana-dana jemaah haji dengan cara yang

$$
\text { hlm. }
$$

${ }^{1}$ Nurul Huda dan Mohamad Heykal, Lembaga Keuangan Islam (Jakarta: Kencana, 2010), https://books.google.co.id/books?id=mo9ADwAAQBAJ\&printsec=frontcover\&dq=Nurul+Huda+da n+Mohamad+Heykal,+Lembaga+Keuangan+Islam\&hl=en\&sa=X\&ved=0ahUKEwiNzuXi3N_fAhXM rY8KHUN6BA0Q6AEIKjAA\#v=onepage\&q=Nurul\%20Huda\%20dan\%20Mohamad\%20Heykal\%2C \%20Lembaga \%20Keuangan\%20Islam\&f=false. 
tidak sama dengan yang dilakukan oleh lembaga keuangan konvensional. Hal ini terjadi dan dilakukan di Malaysia (dahulu bernama Persekutuan Tanah Melayu) dan juga Pakistan. Meskipun begitu, tetap saja lembaga yang didirikan tersebut tidak bisa menggunakan nama Baitut Tamwil dikarenakan hukum yang berlaku adalah hukum dari negara-negara dengan penduduk mayoritas Muslim. Barulah pada tahun 1963, bentuk nyata dari lembaga perbankan Islam mulai terlihat dengan beridirinya Mit Ghamr Local Saving Bank di Mesir, sebuah lembaga keuangan Islam unit desa yang didirikan oleh Ahmed Najjar. ${ }^{2}$

Perbankan syariah yang terus berkembang, menyebabkan persaingan industri perbankan yang sedemikian kompetitif yakni antara perbankan syariah dengan perbankan konvensional, atau sesama bank syariah dalam mendapatkan pendapatannya masing-masing. Salah satu cara yang ditempuh lembaga keuangan adalah dengan meningkatkan penghimpunan dana yang berasal dari masyarakat berupa tabungan. Begitu juga dalam meningkatkan penghimpunan dananya, PT. Bank SUMUT Cabang Syariah Padangsidimpuan menawarkan produk seperti tabungan iB Martabe Bagi Hasil muḍārabah (Marhamah) yaitu salah satu produk tabungan yang berdasarkan prinsip muḍārabah mutlaqah dimana investasi yang dilakukan oleh nasabah dan pihak bank sebagai pengelola dengan nisbah bagi hasil yang telah ditentukan. Tabungan Marhamah merupakan salah satu sumber pendanaan yang cukup besar, oleh karena itu PT. Bank SUMUT Cabang Syariah Padangsidimpuan senantiasa dituntut untuk melakukan usaha yang dapat menarik masyarakat untuk menabung, agar target kenaikan jumlah nasabah yang diharapkan pihak bank dapat terus meningkat dalam setiap tahunnya.

Keputusan nasabah untuk menabung merupakan efek akhir dari suatu pembelian, terdapat beberapa alasan yang menjadi pertimbangan masyarakat memutuskan untuk menjadi nasabah. Alasan tersebut salah satunya karena produk yang ditawarkan oleh suatu bank, tak terkecuali PT. Bank SUMUT Cabang Syariah Padangsidimpuan menawarkan produk tabungan marhamah dengan strategi bagi hasil yang telah ditetapkan, tidak hanya itu bagi nasabah yang beruntung akan mendapatkan insentif berhadiah umroh. Tabungan marhamah sendiri sudah dijamin oleh Lembaga Penjamin Simpanan (LPS).

\footnotetext{
${ }^{2}$ Huda dan Heykal, Lembaga Keuangan...., hlm. 26.
} 
4 | TAZKIR: Jurnal Penelitian Ilmu-ilmu Sosial dan Keislaman

Vol. 04 No. 1 Juni 2018

Dalam menawarkan produk yang dimiliki, bank juga menginformasikan kepada masyarakat melalui kegiatan promosi. Promosi yang dilakukan oleh PT. Bank SUMUT Cabang Syariah Padangsidimpuan adalah dengan melakukan sosialisasi langsung agar lebih efektif untuk calon nasabah baru yang ingin mendapatkan informasi secara jelas dan rinci, tidak hanya itu penyebaran brosur juga dilakukan dalam kegiatan promosi tabungan marhamah. Dengan diadakannya kegiatan promosi maka masyarakat akan mengetahui manfaat apa yang didapatkan dan menambah minat masyarakat untuk menabung. Ketika masyarakat telah memiliki informasi dari kegiatan promosi tersebut, maka tindakan masyarakat selanjutnya adalah melakukan keputusan menjadi nasabah.

Adapun perkembangan jumlah nasabah Tabungan Marhamah di $\quad$ PT. Bank SUMUT Cabang Syariah Padangsidimpuan dapat dilihat pada tabel berikut:

\section{Tabel 1}

Perkembangan Jumlah Nasabah Produk Tabungan Marhamah PT. Bank SUMUT Cabang Syariah Padangsidimpuan

Tahun 2013 s/d 2016

\begin{tabular}{|c|c|c|}
\hline Tahun & Jumlah Nasabah & $\begin{array}{c}\text { Persentase } \\
\text { Kenaikan/ Penurunan }\end{array}$ \\
\hline 2013 & 6478 & - \\
\hline 2014 & 6973 & $7,6 \%$ \\
\hline 2015 & 7818 & $12 \%$ \\
\hline 2016 & 8119 & $3,8 \%$ \\
\hline
\end{tabular}

Sumber : PT. Bank SUMUT Cabang Syariah Padangsidimpuan

Berdasarkan tabel di atas dapat dilihat bahwa perkembangan jumlah Tabungan Marhamah pada tahun 2014 mengalami peningkatan sebanyak 495 nasabah atau sebesar 7,6\%, dan pada tahun 2015 mengalami peningkatan yang lebih besar dari tahun sebelumnya yaitu sebanyak 845 nasabah atau $12 \%$, sedangkan pada tahun 2016 terjadi penurunan yang signifikan yaitu hanya 301 nasabah atau sebesar 3,8\%. Kenaikan yang diharapkan terjadi setiap tahunnya tidak tercapai karena pada tahun 2016 perkembangan jumlah nasabah mengalami penurunan. 
Beberapa penelitian mengenai keputusan menjadi nasabah ini telah banyak dilakukan oleh beberapa peneliti, dengan kesimpulan sebagai berikut:

Khoirul Uyun menyatakan dalam penelitiannya:

Bahwa secara parsial produk syariah berpengaruh signifikan terhadap keputusan nasabah BNI Syariah Cabang Semarang, bauran promosi berpengaruh signifikan terhadap keputusan nasabah BNI Syariah Cabang Semarang dan secara simultan variabel produk syariah dan bauran promosi berpengaruh signifikan terhadap keputusan nasabah BNI Syariah Cabang Semarang. ${ }^{3}$

Sedangkan dalam penelitian Uki Pebruarini menyatakan:

Secara parsial variabel produk dan promosi mempunyai pengaruh positif terhadap keputusan nasabah dalam memilih BMT Sahara Tulungagung. Dan secara bersama-sama produk dan promosi berpengaruh positif signifikan terhadap keputusan nasabah memilih BMT Sahara Tulung Agung. ${ }^{4}$

Dalam penelitian Suhailah Nasution menyatakan bahwa "Secara bersama-sama produk dan promosi berpengaruh signifikan terhadap keputusan nasabah memilih Ar-Rahn pada PT. Pegadaian (Persero) Unit Pelayanan Syariah Sadabuan". ${ }^{5}$

Berdasarkan latar belakang yang telah dikemukakan di atas, maka penelitian ini dimaksudkan untuk mengkaji lebih lanjut seberapa besar produk dan promosi mempengaruhi keputusan nasabah, oleh karenanya tujuan dari penelitian ini adalaj untuk mengetahui berpengaruh produk terhadap keputusan menjadi nasabah Tabungan Marhamah pada PT. Bank SUMUT Cabang Syariah Padangsidimpuan, untuk melihat pengaruh promosi terhadap keputusan menjadi nasabah Tabungan Marhamah pada PT. Bank SUMUT Cabang Syariah Padangsidimpuan, and untuk menguji pengaruh produk dan promosi secara simultan terhadap keputusan menjadi nasabah Tabungan Marhamah pada PT. Bank SUMUT Cabang Syariah Padangsidimpuan.

${ }^{3}$ Khoirul Uyun, "Pengaruh Produk Syariah dan Bauran Promosi Terhadap Keputusan Nasabah Menabung di BNI Cabang Syariah Semarang" (Skripsi, Syariah Institut Agama Islam Negeri Walisongo, 2012), hlm. 99, eprints.ums.ac.id/30634/12/08_Naskah_Publikasi.pdf.

${ }^{4}$ Uki Pebruarini, "Analisis Faktor Strategi Pemasaran Produk Pembiayaan Terhadap Keputusan Nasabah memilih BMT Sahara Tulungagung" (Skripsi, Islam Institut Agama Islam Negeri Tulungagung, 2015), hlm. $\quad 14, \quad$ http://repo.iaintulungagung.ac.id/2273/9/ARTIKEL\%20JURNAL_Skripsi\%20\%28UKI\%20P\%29.pdf.

5 Suhailah Nasution, "Pengaruh Produk dan Promosi terhadap Keputusan Nasabah memiliih Ar-Rahn Pada PT. Pegadaian (Persero) Unit Pelayanan Syariah Sadabuan" (Skripsi, Institut Agama Islam Negeri Padangsidimpuan, 2015), hlm. 62. 
6 | TAZKIR: Jurnal Penelitian Ilmu-ilmu Sosial dan Keislaman

Vol.04 No. 1 Juni 2018

\section{LANDASANTEORI}

\section{Keputusan Nasabah}

Menurut Irham Fahmi pengertian Keputusan adalah "Proses penelusuran masalah yang berawal dari latar belakang masalah, identifikasi masalah hingga kepada terbentuknya kesimpulan dan rekomendasi yang selanjutnya dipakai dan digunakan sebagai pedoman basis dalam pengambilan keputusan dari beberapa aspek pilihan."6 Sedangkan menurut J Supranto "membuat keputusan berarti memilih satu diantara sekian banyak alternatif, dimana minimal terdapat dua pilihan alternatif dan dalam praktiknya lebih dari dua alternatif di mana pengambil atau pembuat keputusan harus memilih salah satu berdasarkan pertimbangan atau kriteria tertentu." ${ }^{\prime 7}$ Berdasarkan pengertian tersebut diatas maka dapat disimpulkan bahwa keputusan adalah proses pemilihan satu tindakan dari dua atau lebih alternatif, yang berawal dari latar belakang masalah, identifikasi masalah, hingga terbentuknya kesimpulan berdasarkan pertimbangan dan kriteria tertentu.

Keputusan konsumen sangat erat hubungannya dengan perilaku konsumen. Perilaku Konsumen menurut Kotler dan Keller adalah "Studi tentang bagaimana individu, kelompok, organisasi memilih, membeli, menggunakan dan bagaimana barang, jasa, ide atau pengalaman untuk memuaskan kebutuhan dan keinginan mereka". ${ }^{8}$ Sedangkan menurut Nembah F. Hartimbul Ginting Perilaku Konsumen adalah "Tindakan perorangan dalam memperoleh, menggunakan serta membuang barang dan jasa ekonomi, termasuk proses pengambilan keputusan sebelum menetapkan tindakan". ${ }^{9}$

Perusahaan yang mengerti betul bagaimana konsumen akan menanggapi berbagai produk, harga dan rangsangan iklan akan memiliki keunggulan dari pesaingnya. Karena, konsumen merupakan salah satu unsur terpenting dalam pemasaran yang menjadi perhatian besar bagi sebuah lembaga bisnis. Hal ini disebabkan konsumen adalah sasaran dari produk baik barang maupun jasa yang dihasilkan produsen.

\footnotetext{
${ }^{6}$ Irham Fahmi, Manajemen Strategis Teori dan Aplikasi (Bandung: Alfabeta, 2014), hlm. 14.

${ }^{7}$ Johannes Supranto, Teknik Pengambilan Keputusan (Jakarta: Rineka Cipta, 2009), hlm. 1.

8 Philip Kotler dan Kevin Lane Keller, Manajemen Pemasaran (Jakarta: Salemba Empat, 2000), hlm. 181.

9 Nembah F. Hartimbul Ginting, Manajemen Pemasaran (Bandung: CV. Yrama Widya, 2011), hlm. 33.
} 
Keputusan yang dilakukan oleh nasabah/konsumen sama halnya dengan perilaku konsumen yaitu sama-sama memberi keputusan pilihan atas tindakan pembelian barang ataupun jasa. Dari pengertian di atas, dapat disimpulkan bahwa perilaku konsumen adalah proses pelanggan dalam membuat keputusan membeli, menggunakan barang-barang dan jasa yang dibeli, juga faktor-faktor yang mempengaruhi keputusan pembelian dan penggunaan produk atau jasa.

\section{Proses Keputusan Nasabah dalam Melakukan Pembelian}

Kegiatan pembelian merupakan suatu rangkaian tindakan fisik maupun mental yang dialami seorang konsumen dalam melakukan tindakan. Tahap-tahap proses keputusan pembelian model lima tahap: ${ }^{10}$

\section{Pengenalan Masalah}

Proses pembelian dimulai ketika pembeli mengenali masalah atau kebutuhan. Kebutuhan tersebut dapat dicetuskan oleh rangsangan internal (lapar, haus dan sebagainya) dan eksternal (menonton iklan televisi). Para pemasar perlu mengidentifikasi keadaan yang memicu kebutuhan tertentu, dengan mengumpulkan informasi dari sejumlah konsumen. Mereka kemudian dapat menyusun strategi pemasaran yang memicu minat konsumen. Ini sangat penting pada proses pembelian dengan kebebasan memilih (discretionary).

Pencarian Informasi. Konsumen yang terangsang kebutuhannya akan terdorong untuk mencari informasi yang lebih banyak. Kita dapat membaginya dalam dua level rangsangan. Situasi pencarian informasi yang lebih ringan dinamakan penguatan perhatian. Pada level ini, orang hanya sekedar lebih peka terhadap informasi produk. Pada level selanjutnya, orang itu akan mulai aktif mencari informasi untuk mempelajari produk tertentu. Yang menjadi perhatian utama pemasar adalah sumber-sumber informasi utama yang menjadi acuan konsumen dan pengaruh relatif tiap sumber tersebut terhadap keputusan pembelian selanjutnya.

Evaluasi Alternatif. Terdapat beberapa proses evaluasi keputusan dan model-model terbaru yang memandang proses evaluasi konsumen sebagai proses yang berorientasi kognitif. Yaitu, model tersebut menganggap konsumen membentuk penilaian atas produk dengan sangat sadar dan rasional. Beberapa konsep dasar akan membantu kita memahami proses evaluasi konsumen.

\footnotetext{
${ }^{10}$ Kotler dan Keller, Manajemen Pemasaran, hlm. 235.
} 
8 | TAZKIR: Jurnal Penelitian Ilmu-ilmu Sosial dan Keislaman

Vol.04 No. 1 Juni 2018

Pertama, konsumen berusaha memenuhi kebutuhan. Kedua, konsumen mencari manfaat tertentu dari solusi produk. Ketiga, konsumen memandang masingmasing produk sebagai sekumpulan atribut dengan kemampuan yang berbedabeda dalam memberikan manfaat yang digunakan untuk memuaskan kebutuhan itu.

Keputusan Pembelian. Dalam tahap evaluasi, para konsumen membentuk preferensi atas merek-merek yang ada di dalam kumpulan pilihan. Konsumen juga dapat membentuk niat untuk membeli merek yang paling disukai. Dalam beberapa kasus, konsumen bisa mengambil keputusan untuk tidak secara formal mengevaluasi setiap merek. Keputusan konsumen untuk memodifikasi, menunda, atau menghindari keputusan pembelian sangat dipengaruhi oleh risiko yang dipikirkan.

\section{Produk}

Menurut Fandy Tjiptono Produk adalah "Sesuatu yang bisa ditawarkan sebagai usaha untuk mencapai tujuan organisasi melalui pemenuhan kebutuhan dan keinginan konsumen, sesuai dengan kompetensi dan kapasitas organisasi serta daya beli pasar".11 Produk secara umum diartikan sebagai sesuatu yang dapat memenuhi kebutuhan dan keinginan pelanggan. Artinya, apa pun wujudnya selama itu dapat memenuhi keinginan pelanggan dan kebutuhan kita katakan sebagai produk. ${ }^{12}$ Termasuk dalam pengertian produk adalah barang atau obyek fisik, jasa atau pelayanan, pengalaman, kegiatan, orang, tempat, properti, organisasi, informasi dan ide serta bauran dari berbagai wujud tersebut. ${ }^{13}$

Produk adalah sesuatu yang memberikan manfaat baik dalam hal memenuhi kebutuhan sehari-hari atau sesuatu yang ingin dimiliki oleh konsumen. Produk biasanya digunakan untuk dikonsumsi baik untuk kebutuhan rohani maupun jasmani. Untuk memenuhi keinginan dan kebutuhan akan produk, maka konsumen harus mengorbankan sesuatu sebagai balas jasanya, misalnya dengan cara pembelian. ${ }^{14}$ Agar produk yang dibuat dapat diterima pasar, maka penciptaan produk haruslah memperhatikan tingkat kualitas yang sesuai dengan keinginan nasabahnya. Produk yang berkualitas tinggi artinya memiliki nilai yang

${ }^{11}$ Fandy Tjiptono, Strategi Pemasaran (Yogyakarta: Andi Publisher, 2015), hlm. 231.

${ }^{12}$ Kasmir, Manajemen Perbankan (Jakarta: Rajawali, 2008), hlm. 195.

${ }^{13}$ M. Nur Rianto Al Arif, Dasar-Dasar Pemasaran Bank Syariah (Bandung: Alfabeta, 2012), hlm. 140.

${ }^{14}$ Kasmir, Pemasaran Bank (Jakarta: Salemba Empat, 2000), hlm. 123. 
lebih baik dibandingkan dengan produk pesaing, agar dapat menarik calon nasabah baru atau mempertahankan nasabah yang lama.

Berdasarkan pendapat diatas, maka dapat disimpulkan bahwa produk adalah sesuatu obyek fisik, jasa atau pelayanan yang ingin dimiliki konsumen untuk memenuhi kebutuhan sehari-hari yang mendatangkan manfaat.

\section{Promosi}

Menurut M. Nur Rianto Promosi adalah "Salah satu kegiatan marketing mix yang merupakan kegiatan yang sangat penting, dalam kegiatan ini setiap bank berusaha untuk mempromosikan seluruh produk dan jasa yang dimilikinya baik langsung maupun tidak langsung."15 Sedangkan menurut Asnawi dan Masyhuri "Salah satu sarana pemasaran perusahaan yang bertujuan agar produk yang dipasarkan dapat dikenal secara luas oleh pihak konsumen, sehingga diharapkan dapat meningkatkan volume penjualan."16 Oleh karena itu, promosi merupakan sarana yang paling ampuh untuk menarik calon nasabah yang baru. Kemudian promosi juga berfungsi mengingatkan nasabah akan produk, promosi juga ikut mempengaruhi nasabah untuk membeli dan akhirnya promosi juga akan meningkatkan citra bank dimata para nasabahnya. Sesuai dengan firman Allah SWT. yang berkaitan dengan promosi disampaikan dalam Al-Quran Surat AnNisa ayat 58, yang artinya: "Sesungguhnya Allah menyuruh kamu menyampaikan amanat kepada yang berhak menerimanya, dan (menyuruh kamu) apabila menetapkan hukum di antara manusia supaya kamu menetapkan dengan adil. Sesungguhnya Allah memberi pengajaran yang sebaik-baiknya kepadamu. Sesungguhnya Allah adalah Maha Mendengar lagi Maha Melihat" (An-Nisa: 58). ${ }^{17}$

Hubungan dari ayat ini dengan kegiatan promosi adalah amanat dalam melakukan kegiatan, salah satunya kegiatan promosi. Dimana amanat maksudnya adalah menyampaikan hak ataupun apa saja kepada pemiliknya dengan tidak ada pengurangan dan kecurangan didalamnya.

${ }^{15}$ Al Arif, Dasar-Dasar Pemasaran Bank Syariah, hlm. 168.

${ }^{16}$ Nur Asnawi dan Masyhuri, Metodologi Riset Manajemen Pemasaran (Malang: UIN Maliki Press, 2011), hlm. 96.

17 Departemen Agama, Al-Quran dan Terjemahannya (Bandung: PT. Sygma Examedia Arkanleema, 2007), hlm. 87. 
10 | TAZKIR: Jurnal Penelitian Ilmu-ilmu Sosial dan Keislaman

Vol. 04 No. 1 Juni 2018

\section{Pengaruh Produk dengan Keputusan Nasabah}

Setiap perusahaan selalu berusaha untuk memenuhi kebutuhan dan keinginan konsumen melalui produk yang ditawarkan, sedangkan konsumen mencari manfaat-manfaat tertentu yang ada pada suatu produk. Seorang konsumen sebelum melakukan keputusan pembelian akan sebuah produk, konsumen memulai dari pengenalan masalah untuk mengetahui apa yang mereka butuhkan. Dari beberapa informasi yang didapat, diperoleh beberapa alternatif pilihan mengenai produk, kemudian konsumen melakukan penilaian atas alternatif produk yang paling bermanfaat bagi konsumen.

Hagi Anggriawan mengatakan bahwa "Atribut produk mempunyai pengaruh yang sangat besar bagi keputusan pembelian konsumen terhadap suatu produk yang ditawarkan, dan dapat memenuhi kebutuhannya". ${ }^{18}$ Sedangkan Eka Wundi Lilis menyatakan bahwa "Variabel produk secara parsial berpengaruh signifikan terhadap keputusan menjadi nasabah tabungan faedah Bank BRI Syariah Cabang Semarang". ${ }^{19}$ Detha Fajrin mengatakan bahwa "Produk berpengaruh positif dan signifikan terhadap proses keputusan menabung". ${ }^{20}$

Hasil pemaparan penelitian di atas dapat disimpulkan bahwa, produk yang berkualitas sesuai dengan kebutuhan/keinginan konsumen memberikan pengaruh terhadap keputusan menjadi nasabah. Dengan ini, perusahaan perlu memperhatikan produk yang dibutuhkan seorang konsumen.

\section{Pengaruh Promosi dengan Keputusan Nasalah}

Pada bagian promosi, peran komunikasi menjadi penting karena komunikasi merupakan pertukaran komunikasi antar pihak bank dan nasabah, pertukarakan informasi sangat penting bagi peningkatan hubungan pemasaran, hal ini karena informasi memberikan kesadaran dan pengertian antara pihak

18 Hagi Anggriawan, "Pengaruh Atribut Produk Tabungan Berjangka Terhadap Keputusan Nasabah PT. Himpunan Saudara 1906 Tbk. KC Wastukencana Bandung" (Skripsi, Universitas Widyatama, 2012), hlm. 33, https://repository.widyatama.ac.id/xmlui/handle/123456789/2590.

19 Eka Wundi Lilis Kustiningsih, "Variabel-Variabel Yang Mempengaruhi Keputusan Menjadi Nasabah Tabungan Faedah Bank BRI Syariah Cabang Samarinda," eJournal Ilmu Administrasi Bisnis 2, no. 2 (2014): hlm. 211.

20 Detha Alfrian Fajri, Zainul Arifin, dan Wilopo, "Pengaruh Bauran Pemasaran Jasa terhadap Keputusan Menabung Survei Nasabah Bank Muamalat Cabang Malang," Jurnal Administrasi Bisnis, t.t., hlm. 9, https://media.neliti.com/media/publications/77977-ID-pengaruhbauran-pemasaran-jasa-terhadap.pdf. 
bank dan nasabah. Informasi yang tersedia akan menentukan banyak alternatif yang akan dievaluasi. Semakin banyaknya media dan makin menarik suatu promosi akan mempengaruhi suatu keputusan nasabah untuk menggunakan jasa perbankan.

Atanasius Hardian Permana mengatakan dalam penelitiannya bahwa "Promosi berpengaruh positif dan signifikan terhadap keputusan penggunaan jasa perbankan syariah tabungan mudharabah". ${ }^{21}$ Kusmuriyanto dan Martono mengatakan "Keputusan menabung pada BNI Taplus secara bersama-sama dipengaruhi oleh faktor promosi". ${ }^{22}$ Hasil pemaparan penelitian di atas dapat disimpulkan bahwa, dengan promosi nasabah dapat mengetahui produk yang ditawarkan pihak bank agar dapat memutuskan untuk membeli produk tersebut dan harus sesuai dengan kebutuhan dan keinginan nasabah.

\section{Kerangka Pikir}

Berdasarkan kajian teori di atas peneliti mengkaji dan meneliti apakah produk dan promosi berpengaruh terhadap keputusan menjadi nasabah Tabungan Marhamah pada PT. Bank SUMUT Cabang Syariah Padangsidimpuan. Kerangka pemikiran disajikan untuk menggambarkan hubungan dari variabel independen, dalam hal ini adalah $\left(\mathrm{X}_{1}\right)$ faktor produk, $\left(\mathrm{X}_{2}\right)$ faktor promosi terhadap keputusan menjadi nasabah Tabungan Marhamah (Y). Maka peneliti membuat sebuah kerangka pikir sebagai berikut:

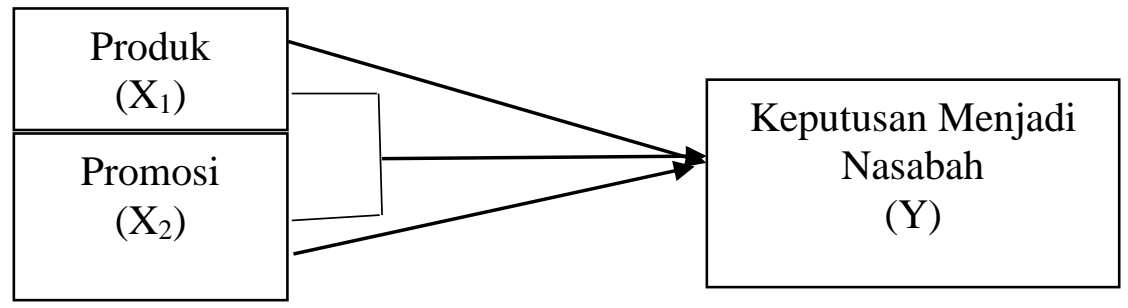

21 Atanasius Hardian Permana, "Pengaruh Bagi Hasil, Promosi, dan Kualitas Pelayanan Terhadap Keputusan Penggunaan Jasa Perbankan Syariah Tabungan Mudharabah" (Skrips, Universitas Negeri Yogyakarta, 2015), hlm. 92.

${ }^{22}$ Kusmuriyanto dan S. Martono, “Daya Tarik Bauran Promosi Untuk Produk Tabungan Plus BNI 1946 (Analisis Keputusan Menabung Pada Bank BNI Cabang Semarang)," Dinamika 11, no. 2 (2002): hlm. 31. 
12 | TAZKIR: Jurnal Penelitian Ilmu-ilmu Sosial dan Keislaman

Vol. 04 No. 1 Juni 2018

\section{Metode Penelitian}

Penelitian ini berlokasi di PT. Bank SUMUT Cabang Syariah Padangsidimpuan di Jalan Jend. Sudirman Ex. Merdeka No. 12 Kota Padangsidimpuan/22718. Sedangkan waktu yang dibutuhkan dalam penyelesaian penelitian ini mulai bulan September sampai dengan Desember 2017. Jenis penelitian yang dipakai adalah penelitian kuantitatif. Penelitian kuantitatif adalah penelitian yang bekerja dengan angka, yang datanya berwujud bilangan (skor atau nilai, peringkat atau frekuensi) yang dianalisis dengan menggunakan statistik untuk menjawab pertanyaan atau hipotesis penelitian yang sifatnya spesifik, dan untuk melakukan prediksi bahwa suatu variabel tertentu mempengaruhi variabel lain. ${ }^{23}$ Penelitian ini adalah penelitian kuantitatif analisis deskriptif. Deskriptif yaitu menggambarkan dan menginterpretasikan obyek penelitian secara apa adanya sesuai dengan hasil penelitian. Populasi penelitian ini adalah semua nasabah aktif yang menggunakan Tabungan Marhamah pada PT. Bank SUMUT Cabang Syariah Padangsidimpuan yang berjumlah 8119 nasabah. Dalam menentukan jumlah sampel digunakan rumus Slovin, sehingga banyaknya sampel penelitian adalah 99 nasabah. Sedangkan penentuan sampelnya digunakan random sampling yaitu pengambilan sampel dilakukan melalui sistem acak. Maka peneliti memberikan hak yang sama kepada setiap subjek untuk memperoleh kesempatan dipilih menjadi sampel. ${ }^{24}$

Adapun metode pengumpulan data yang digunakan peneliti dalam penelitian ini adalah angket denga kisi-kisi sebagai berikut:

\section{Tabel 4}

Kisi-kisi Angket

\begin{tabular}{|c|c|c|c|}
\hline No & Variabel & Indikator & Nomor Soal \\
\hline \multirow{5}{*}{1} & & 1. Merek & 1 \\
\hline & Produk & 2. Kemasan & 2 dan 3 \\
\hline & & 3. Kualitas & 4 dan 5 \\
\hline & & 4. Pelayanan & 6,7 dan 8 \\
\hline & \multicolumn{2}{|c|}{ Jumlah } & 8 \\
\hline
\end{tabular}

${ }^{23}$ Asmadi Alsa, Pendekatan Kuantitatif dan Kualitatif (Yogyakarta: Pustaka Pelajar, 2003) hlm. 13.

${ }^{24}$ Husein Umar, Metode Penelitian untuk Skripsi dan Tesis Bisnis (Jakarta: PT. Raja Grafindo Persada, 2009), hlm. 82. 


\begin{tabular}{|c|c|c|c|}
\hline & & 1. Periklanan & 1 dan 2 \\
\hline \multirow[t]{4}{*}{2} & Promosi & 2. Promosi Penjualan & 3 dan 4 \\
\hline & & 3. Publisitas & 5 dan 6 \\
\hline & & 4. Penjualan Pribadi & 7 dan 8 \\
\hline & \multicolumn{2}{|c|}{ Jumlah } & 8 \\
\hline \multirow{7}{*}{3} & \multirow{6}{*}{ Keputusan } & 1. Pengenalan Masalah & 1 \\
\hline & & 2. Pencarian Informasi & 2,3 dan 4 \\
\hline & & 3. Penilaian Alternatif & 5 dan 6 \\
\hline & & 4. Keputusan Pembeliaan & 7 \\
\hline & & 5. Perilaku Setelah & 8 \\
\hline & & Pembelian & \\
\hline & \multicolumn{2}{|c|}{ Jumlah } & 8 \\
\hline
\end{tabular}

Teknik analisis data yang digunakan dalam penelitian ini dengan menggunakan program Statistical Product and Service Solution atau SPSS versi 22 sebagai berikut:
a. Uji Validitas dan Reliabilitas
b. Uji Statistik Deskriftif
c. Uji Normalitas
d. Uji Lineritas
e. Uji Asumsi Klasik
f. Analisis Regresi Berganda
g. Koefisien Determinasi
h.Uji Hipotesis

\section{Hasil dan Pembahasan}

\section{Hasil Penelitian}

Berdasarkan hasil pengolahan data dengan bantuan program SPSS 22, maka diperoleh hasil sebagai berikut:

Uji Validitas dan reliabilitas

Pengujian data validitas untuk setiap pertanyaan angket dari masingmasing variable dinyataan valid karena nilai rhitung lebih besar dari rtabel yaitu sebesar 0,166 dengan tingkat signifikan 0,1 dan sampel 99. Sementara uji reliabilitas dimana nilai Cronbach's Alpha dari masing-masing variable berada diatas ketentuan yaitu 0,600 . 
14 | TAZKIR: Jurnal Penelitian Ilmu-ilmu Sosial dan Keislaman

Vol. 04 No. 1 Juni 2018

Uji Statistik

Berdasarkan uji statistic dengan menggunakan program SPSS versi 22 diperoleh hasil bahwa variabel Produk dengan jumlah data (N) sebanyak 99 mempunyai nilai mean sebesar 31,14 dengan nilai mimimum 19 dan nilai maksimum 40 serta standar deviasinya sebesar 3,623. Variabel Promosi dengan jumlah data $(\mathrm{N})$ sebanyak 99 mempunyai nilai mean sebesar 33,03 dengan nilai mimimum 19 dan nilai maksimum 40 serta standar deviasinya sebesar 4,024. Variabel Keputusan dengan jumlah data $(\mathrm{N})$ sebanyak 99 mempunyai nilai mean sebesar 33,63 dengan nilai minimum 18 dan nilai maksimum 40 serta standar deviasinya sebesar 3,056.

Uji Normalitas

Dalam uji normalitas diperoleh hasil bahwa variabel Produk nilai Kolmogrov-Smirnov $\mathrm{Z}$ sebesar 0,222 > 0,1 maka variabel Produk $\left(\mathrm{X}_{1}\right)$ memenuhi asumsi normalitas. Variabel Promosi nilai Kolmogrov-Smirnov Z sebesar 0,125 > 0,1 maka variabel Promosi $\left(\mathrm{X}_{2}\right)$ memenuhi asumsi normalitas. Variabel Keputusan nilai Kolmogrov-Smirnov $\mathrm{Z}$ sebesar 0,176 > 0,1 maka variabel Keputusan ( $\mathrm{Y}$ ) memenuhi asumsi normalitas.

Uji Asumsi Klasik

Dalam hasil pengolahan data penelitian melalui SPSS dinyatakan bahwa seluruh variable penelitian terbebas dari asumsi klasik.

Uji Analisis Regresi Berganda

Analisis regresi linier berganda yang digunakan dalam penelitian ini untuk mengetahui pengaruh Produk $\left(\mathrm{X}_{1}\right)$, Promosi $\left(\mathrm{X}_{2}\right)$ terhadap Keputusan $(\mathrm{Y})$, dengan hasil berikut ini:

Tabel 5

Hasil Uji Analisis Regresi Linier Berganda

\begin{tabular}{|c|c|c|c|c|c|c|}
\hline \multirow{4}{*}{\multicolumn{2}{|c|}{ Model }} & \multirow{3}{*}{\multicolumn{2}{|c|}{$\begin{array}{c}\text { Unstandardized } \\
\text { Coefficients }\end{array}$}} & \multirow{3}{*}{$\begin{array}{c}\text { Standardiz } \\
\text { ed } \\
\text { Coefficients }\end{array}$} & \multirow[b]{4}{*}{$\mathrm{T}$} & \multirow[b]{4}{*}{ Sig. } \\
\hline & & & & & & \\
\hline & & & & & & \\
\hline & & B & Std. Error & Beta & & \\
\hline \multirow[t]{3}{*}{1} & (Constant) & 23,715 & 3,058 & & 7,756 & ,000 \\
\hline & Produk & 145 & 087 & 171 & 1,667 & ,099 \\
\hline & Promosi & 164 & 078 & 216 & 2,100 & ,038 \\
\hline
\end{tabular}


a. Dependent Variable: Keputusan

Sumber: Hasil output SPSS versi 22 (data diolah, 2017)

Berdasarkan tabel di atas, maka persamaan analisis regresi linier berganda dalam penelitian ini adalah:

$$
\mathrm{KMN}=23,715+0,145 \text { Prod + 0,164Prom }
$$

Persamaan regresi tersebut dapat dijelaskan sebagai berikut:

a) Koefisien regresi variabel Produk sebesar 0,145, artinya apabila tingkat Produk meningkat 1 satuan maka Keputusan Menjadi Nasabah meningkat sebesar $14,5 \%$

b) Koefisien bernilai positif artinya terjadi hubungan antara Produk dengan Keputusan Menjadi Nasabah.

Nilai koefisien determinasi adalah di antara nol dan satu.

Tabel 6

Hasil Uji Koefisien Determinasi

\begin{tabular}{|c|c|c|c|c|}
\hline Model & $\mathrm{R}$ & R Square & $\begin{array}{c}\text { Adjusted R } \\
\text { Square }\end{array}$ & $\begin{array}{l}\text { Std. Error of the } \\
\text { Estimate }\end{array}$ \\
\hline 1 & $465^{\mathrm{a}}$ & ,216 & 200 & 1,63755 \\
\hline
\end{tabular}

a. Predictors: (Constant), Promosi, Produk

Sumber: Hasil output SPSS versi 22 (data diolah, 2017)

Dari tabel di atas dapat diketahui bahwa angka $R$ Square sebesar 0,216. Hal ini menunjukkan bahwa persentase sumbangan pengaruh variabel Produk dan Promosi terhadap variabel Keputusan adalah sebesar 21,6\% sedangkan sisanya sebesar 78,4\% dipengaruhi atau dijelaskan oleh variabel lain yang tidak dimasukkan dalam penelitian ini.

Uji Hipotesis

Berdasarkan hasil pengolahan data melalui SPSS diperoleh hasil:

Tabel 7

Hasil Uji Signifikansi Parsial (Uji t)

\begin{tabular}{lccccc}
\hline & \multicolumn{2}{c}{ Unstandardized } & \multicolumn{2}{c}{ Standardized } & \\
& Coefficients & Coefficients & & \\
Model & B & Std. Error & Beta & t & Sig. \\
\hline
\end{tabular}


16 | TAZKIR: Jurnal Penelitian Ilmu-ilmu Sosial dan Keislaman

Vol. 04 No. 1 Juni 2018

\begin{tabular}{rrrrrrr}
\hline 1 & (Constant) & 23,715 & 3,058 & & 7,756 &, 000 \\
& Produk &, 145 &, 087 &, 171 & 1,667 &, 099 \\
& Promosi &, 164 &, 078 &, 216 & 2,100 &, 038 \\
\hline
\end{tabular}

a. Dependent Variable: Keputusan

Sumber: Hasil output SPSS versi 22 (data diolah, 2017)

Untuk tabel dicari pada $\alpha=10 \%: 2=5 \%$ (uji dua sisi) dengan derajat kebebasan $(\mathrm{df})=\mathrm{n}-\mathrm{k}-1$, dimana $\mathrm{n}=$ jumlah sampel dan $\mathrm{k}=$ jumlah variabel independen, jadi $\mathrm{df}=99-2-1=96$, maka diperoleh tabel sebesar 1,660. Berdasarkan hasil uji signifikansi parsial (uji t) di atas dapat dilihat bahwa pada variabel Produk memiliki thitung sebesar 1,667 ttabel sebesar 1,660 sehingga thitung $>t_{\text {tabel }}(1,667>$ 1,660). Selanjutnya, berdasarkan nilai Sig. Variabel Produk memiliki nilai Sig. sebesar 0,099 sehingga nilai Sig. $<0,1(0,099<0,1)$ maka $\mathrm{H}_{1}$ diterima. Jadi, dapat disimpulkan bahwa secara parsial Produk mempunyai pengaruh yang signifikan terhadap Keputusan Menjadi Nasabah.

Pada variabel Promosi memiliki thitung sebesar 2,100 tabel sebesar 1,660 sehingga thitung $>$ tabel $(2,100>1,660)$. Selanjutnya, berdasarkan nilai Sig. Variabel Promosi memiliki nilai Sig. sebesar 0,038 sehingga nilai Sig. $<0,1(0,038<0,1)$ maka $\mathrm{H}_{2}$ diterima. Jadi, dapat disimpulkan bahwa secara parsial Promosi mempunyai pengaruh yang signifikan terhadap Keputusan Menjadi Nasabah.

Sedangkan untuk simultan (uji F) diperoleh hasil:

\section{Tabel 8}

Hasil Uji Signifikansi Simultan (Uji F)

\begin{tabular}{|c|c|c|c|c|c|c|}
\hline Model & & $\begin{array}{l}\text { Sum of } \\
\text { Squares }\end{array}$ & Df & $\begin{array}{l}\text { Mean } \\
\text { Square }\end{array}$ & $\mathrm{F}$ & Sig. \\
\hline \multirow[t]{3}{*}{1} & $\begin{array}{l}\text { Regressio } \\
\mathrm{n}\end{array}$ & 92,098 & 2 & 46,049 & 5,371 &, $006^{\mathrm{b}}$ \\
\hline & Residual & 823,073 & 96 & 8,574 & & \\
\hline & Total & 915,172 & 98 & & & \\
\hline
\end{tabular}

a. Dependent Variable: Keputusan

b. Predictors: (Constant), Promosi, Produk

Dari hasil uji Signifikansi di atas dapat bahwa nilai Fhitung adalah 5,371 sedangkan $F_{\text {tabel }}$ untuk signifikansi $\alpha=0,1$ dengan df1 (jumlah variabel -1 ) $=2$ dan df2 (n-k-1) atau 99-2-1 = 96 ( $\mathrm{n}$ adalah jumlah data dan $\mathrm{k}$ adalah jumlah variabel 
independent), hasil yang diperoleh untuk $F_{\text {tabel }}$ sebesar 2,36. Karena Fhitung $>F_{\text {tabel }}$ $(5,371>2,36)$ maka $\mathrm{H}_{3}$ diterima. Selanjutnya, untuk nilai sig. sebesar 0,006 sehingga nilai sig. $<0,1(0,006<0,1)$ maka $\mathrm{H}_{3}$ diterima Jadi dapat disimpulkan bahwa Produk dan Promosi secara bersama-sama berpengaruh terhadap Keputusan Menjadi Nasabah.

\section{Pembahasan Hasil Penelitian}

Pengaruh Produk Terhadap Keputusan Menjadi Nasabah Tabungan Marhamah pada PT. Bank SUMUT Cabang Syariah Padangsidimpuan

Secara parsial Produk mempunyai pengaruh terhadap Keputusan Menjadi Nasabah dengan nilai thitung $>$ ttabel $(1,667>1,660)$ dan nilai Sig. $<\alpha(0,099<$ $0,1)$. Hasil ini sesuai dengan pernyataan Sofjan Assauri yang menyatakan Tujuan utama dari strategi produk adalah untuk dapat mencapai sasaran pasar yang dituju dengan meningkatkan kemampuan bersaing atau mengatasi persaingan dan konsisten dengan penelitian yang dilakukan Detha Fajrin mengatakan bahwa Produk berpengaruh positif dan signifikan terhadap proses keputusan menabung.

Pengaruh Promosi Terhadap Keputusan Menjadi Nasabah Tabungan Marhmah Pada PT. Bank SUMUT Cabang Syariah Padangsidimpuan

Secara parsial variabel Promosi mempunyai pengaruh terhadap Keputusan Nasabah dengan nilai thitung $>$ tabel $(2,100>1,660)$ dan nilai Sig. $<\alpha$ $(0,038<0,1)$. Menyatakan bahwa setiap kenaikan Promosi Penjualan 1 satuan maka akan meningkatkan Keputusan Nasabah Tabungan Marhamah Pada PT. Bank SUMUT Cabang Syariah Padangsidimpuan sebesar 2,100. Sesuai dengan pernyataan Asnawi dan Mashyuri Promosi salah satu sarana pemasaran perusahaan yang bertujuan agar produk yang dipasarkan dapat dikenal secara luas oleh pihak konsumen, sehingga diharapkan dapat meningkatkan volume penjualan.

Pengaruh Produk dan Promosi terhadap Keputusan Menjadi Nasabah Tabungan Marhamah Pada PT. Bank SUMUT Cabang Syariah Padangsidimpuan.

Secara simultan variabel Produk dan Promosi mempunyai pengaruh terhadap Keputusan Nasabah dengan nilai thitung $>$ tabel $\quad(5,371>2,36)$ dan nilai Sig. $<\alpha(0,006<0,1)$ Menyatakan bahwa setiap kenaikan Produk dan Promosi 1 satuan maka akan meningkatkan Keputusan Menjadi Nasabah Pada PT. Bank SUMUT Cabang Syariah Padangsidimpuan sebesar 5,371. 
18 | TAZKIR: Jurnal Penelitian Ilmu-ilmu Sosial dan Keislaman

Vol. 04 No. 1 Juni 2018

Hasil penelitian ini konsisten dengan hasil penelitian yang dilakukan oleh Suhailah Nasution yang menyatakan bahwa faktor Produk dan Promosi secara bersama-sama berpengaruh signifikan terhadap keputusan nasabah.

\section{PENUTUP}

Berdasarkan hasil penelitian dan pembahasan, maka kesimpulan yang dapat diperoleh sebagai berikut:

1. Secara parsial variabel Produk berpengaruh terhadap Keputusan Menjadi Nasabah Tabungan Marhamah Pada PT. Bank SUMUT Cabang Syariah Padangsidimpuan.

2. Secara parsial variabel Produk berpengaruh terhadap Keputusan Menjadi Nasabah Tabungan Marhamah Pada PT. Bank SUMUT Cabang Syariah Padangsidimpuan.

3. secara simultan (bersama-sama) variabel Produk dan Promosi berpengaruh terhadap Keputusan Menjadi Nasabah Tabungan Marhamah Pada PT. Bank SUMUT Cabang Syariah Padangsidimpuan.

4. Secara simultan bahwa keseluruhan variabel bebas (independen) terhadap variabel terikat (dependen) adalah sebesar 0,216 atau 21,6\% sedangkan 78,4\% sisanya dipengaruhi oleh variabel independen lain yang tidak dibahas dalam penelitian ini. 


\section{DAFTAR PUSTAKA}

Al Arif, M. Nur Rianto. Dasar-Dasar Pemasaran Bank Syariah. Bandung: Alfabeta, 2012.

Alsa, Asmadi. Pendekatan Kuantitatif dan Kualitatif. Yogyakarta: Pustaka Pelajar, 2003.

Anggriawan, Hagi. “Pengaruh Atribut Produk Tabungan Berjangka Terhadap Keputusan Nasabah PT. Himpunan Saudara 1906 Tbk. KC Wastukencana Bandung." Skripsi, Universitas Widyatama, 2012. https://repository.widyatama.ac.id/xmlui/handle/123456789/2590.

Asnawi, Nur, dan Masyhuri. Metodologi Riset Manajemen Pemasaran. Malang: UIN Maliki Press, 2011.

Departemen Agama. Al-Quran dan Terjemahannya. Bandung: PT. Sygma Examedia Arkanleema, 2007.

Fahmi, Irham. Manajemen Strategis Teori dan Aplikasi. Bandung: Alfabeta, 2014.

Fajri, Detha Alfrian, Zainul Arifin, dan Wilopo. “Pengaruh Bauran Pemasaran Jasa terhadap Keputusan Menabung Survei Nasabah Bank Muamalat Cabang Malang." Jurnal Administrasi Bisnis, t.t. https://media.neliti.com/media/publications/77977-ID-pengaruh-bauranpemasaran-jasa-terhadap.pdf.

Ginting, Nembah F. Hartimbul. Manajemen Pemasaran. Bandung: CV. Yrama Widya, 2011.

Huda, Nurul, dan Mohamad Heykal. Lembaga Keuangan Islam. Jakarta: Kencana, 2010.

https://books.google.co.id/books?id=mo9ADwAAQBAJ\&printsec=frontco ver\&dq=Nurul+Huda+dan+Mohamad + Heykal, + Lembaga + Keuangan+Isla m\&hl=en\&sa=X\&ved=0ahUKEwiNzuXi3N_fAhXMrY8KHUN6BA0Q6AE IKjAA\# $\mathrm{v}=$ onepage\&q=Nurul\%20Huda\%20dan\%20Mohamad\%20Heykal $\% 2 \mathrm{C} \% 20$ Lembaga $\% 20$ Keuangan $\% 20$ Islam\&f=false.

Kasmir. Manajemen Perbankan. Jakarta: Rajawali, 2008.

- - - Pemasaran Bank. Jakarta: Salemba Empat, 2000.

Kotler, Philip, dan Kevin Lane Keller. Manajemen Pemasaran. Jakarta: Salemba Empat, 2000. 
20 | TAZKIR: Jurnal Penelitian Ilmu-ilmu Sosial dan Keislaman

Vol. 04 No. 1 Juni 2018

Kusmuriyanto, dan S. Martono. "Daya Tarik Bauran Promosi Untuk Produk Tabungan Plus BNI 1946 (Analisis Keputusan Menabung Pada Bank BNI Cabang Semarang)." Dinamika 11, no. 2 (2002): 27-32.

Kustiningsih, Eka Wundi Lilis. "Variabel-Variabel Yang Mempengaruhi Keputusan Menjadi Nasabah Tabungan Faedah Bank BRI Syariah Cabang Samarinda." eJournal Ilmu Administrasi Bisnis 2, no. 2 (2014): 201-14.

Nasution, Suhailah. "Pengaruh Produk dan Promosi terhadap Keputusan Nasabah memiliih Ar-Rahn Pada PT. Pegadaian (Persero) Unit Pelayanan Syariah Sadabuan." Skripsi, Institut Agama Islam Negeri Padangsidimpuan, 2015.

Pebruarini, Uki. "Analisis Faktor Strategi Pemasaran Produk Pembiayaan Terhadap Keputusan Nasabah memilih BMT Sahara Tulungagung." Skripsi, Islam Institut Agama Islam Negeri Tulungagung, 2015. http://repo.iaintulungagung.ac.id/2273/9/ARTIKEL\%20JURNAL_Skripsi\%20\%28UKI\%20 P\%29.pdf.

Permana, Atanasius Hardian. "Pengaruh Bagi Hasil, Promosi, dan Kualitas Pelayanan Terhadap Keputusan Penggunaan Jasa Perbankan Syariah Tabungan Mudharabah." Skrips, Universitas Negeri Yogyakarta, 2015.

Rangkuti, Ahmad Nizar. Metode Penelitian Pendidikan Pendekatan Kuantitatif, Kualitatif, PTK, dan Penelitian pengembangan. Bandung: Citapustaka Media, 2014.

Supranto, Johannes. Teknik Pengambilan Keputusan. Jakarta: Rineka Cipta, 2009.

Tjiptono, Fandy. Strategi Pemasaran. Yogyakarta: Andi Publisher, 2015.

Umar, Husein. Metode Penelitian untuk Skripsi dan Tesis Bisnis. Jakarta: PT. Raja Grafindo Persada, 2009.

Uyun, Khoirul. "Pengaruh Produk Syariah dan Bauran Promosi Terhadap Keputusan Nasabah Menabung di BNI Cabang Syariah Semarang." Skripsi, Syariah Institut Agama Islam Negeri Walisongo, 2012. eprints.ums.ac.id/30634/12/08_Naskah_Publikasi.pdf. 